Литвин Валентина Анатоліївна доктор філософії, викладач кафедри педагогіки, психології, початкової освіти та освітнього менеджменту, Комунальний заклад «Харківська гуманітарно-педагогічна академія» Харківської обласної ради, пров. Руставелі, 7, м. Харків, 61000, тел.: (057) 732-87-33, e-mail: mrs.valentynka@gmail.com, https://orcid.org/0000-0001-6943-792X

\title{
МІЖНАРОДНИЙ ДОСВІД РОЗВИТКУ СИСТЕМИ ПІДВИЩЕННЯ КВАЛІФІКАЦІЇ НАУКОВО-ПЕДАГОГІЧНИХ ПРАЦІВНИКІВ ЗАКЛАДІВ ВИЩОЇ ОСВІТИ
}

Анотація. У статті проаналізовано міжнародний досвід розвитку системи підвищення кваліфікації науково-педагогічних працівників закладів вищої освіти. Досліджено, що в країнах Європейського Союзу велике значення надається професійній підготовці та перепідготовці науково-педагогічних працівників. Неперервна освіта науково-педагогічних працівників у сучасних умовах розуміється як системне поєднання формальної, неформальної та інформальної освіти, що супроводжує професійну сферу. Проблеми якісної підготовки, перепідготовки та підвищення їхньої кваліфікації $є$ актуальною як для України, так і для зарубіжних країн, тому що педагогічна освіта постійно актуалізується у зв'язку з розвитком тенденцій у суспільстві.

Схарактеризовано, що в сучасних умовах необхідна диференціація й індивідуалізація науково-методичного, технічного супроводу в процесі підвищення кваліфікації науково-педагогічних працівників закладів вищої освіти. Однією із можливостей використання позитивного досвіду підвищення кваліфікації науково-педагогічних працівників Великобританії, Німеччині та США є створення мережі центрів, філій, підрозділів, професійних асоціацій та спілок із розроблення освітніх програм, що просувають інновації й передовий досвід у сфері вищої освіти, до завдань яких віднесено підвищення професійного та освітнього розвитку кваліфікацій досвідчених і молодих науково-педагогічних працівників. Підвищення кваліфікації НПП та педагогічних працівників у Фінляндії, Франції та Греції забезпечується безпосередньо навчальними закладами, різноманітними установами післядипломної освіти, відділами освіти, університетськими інститутами та регіональними центрами освіти; серед організаційних форм професійного розвитку НПП: пропедевтичне, періодичне, спеціальне підвищення кваліфікації та перепідготовка. У Канаді підвищення кваліфікації НПП забезпечується різноманітними програмами сертифікації педагогів; департаментами освіти, які управляють розвитком національної політики в галузі освіти; регіональними центрами освіти; спілками та приватними постачальниками послуг професійного розвитку НПП, діяльність яких 
спрямована на організацію підвищення кваліфікації. У Китайській народній республіці (КНР) підвищення кваліфікації НПП відбувається у взаємодії курсів підвищення кваліфікації, заходів на базі навчального закладу та самоосвіти педагога; підвищення кваліфікації здійснюється за денною, вечірньою, заочною та дистанційною формами навчання й будується 3 урахуванням педагогічного стажу, рівня педагогічної кваліфікації й необхідності методичного удосконалення.

3'ясовано, що в процесі підвищення кваліфікації науково-педагогічних працівників закладів вищої освіти зарубіжних країн особлива увага приділяється можливості постійного доступу НПП до нового актуального бекграунду щодо новітніх розробок, дистанційних курсів підвищення кваліфікації, проєктування індивідуального освітнього маршруту, задоволення освітніх потреб особистості НПП тощо.

Ключові слова: міжнародний досвід, підвищення кваліфікації, науковопедагогічні працівники, світовий освітній простір, форми та методи підвищення кваліфікації науково-педагогічних працівників.

Lytvyn Valentyna Anatoliivna Doctor of Philosophy, Teacher at the Department of Pedagogy, Psychology, Primary Education and Education Management, Municipal Establishment "Kharkiv Humanitarian-Pedagogical Academy" of the Kharkiv Regional Council, Rustaveli Lane, 7, Kharkiv, 61000, tel.: (057) 732-87-33, e-mail: mrs.valentynka@gmail.com, https://orcid.org/0000-0001-6943-792X

\section{INTERNATIONAL EXPERIENCE OF DEVELOPMENT OF THE QUALIFICATION DEVELOPMENT SYSTEM OF SCIENTIFIC AND PEDAGOGICAL EMPLOYEES OF HIGHER EDUCATION INSTITUTIONS}

Abstract. The article analyzes the international experience of development of the system of advanced training of scientific and pedagogical workers of higher education institutions. It is investigated that in the countries of the European Union great importance is attached to the professional training and retraining of scientific and pedagogical workers. Continuing education of research and teaching staff in modern conditions is understood as a systematic combination of formal, non-formal and informal education that accompanies the professional sphere. The problems of quality training, retraining and advanced training are relevant for both Ukraine and foreign countries, because pedagogical education is constantly updated in connection with the development of trends in society.

It is characterized that in modern conditions it is necessary to differentiate and individualize scientific and methodological, technical support in the process of professional development of scientific and pedagogical staff of higher education institutions. One of the opportunities to use the positive experience of professional development of research and teaching staff in the UK, Germany and the United States is to create a network of centers, branches, units, professional associations and unions 
to develop educational programs that promote innovation and excellence in higher education, raising the professional and educational development skills of experienced and young research and teaching staff. Further training of scientific and pedagogical workers and teachers in Finland, France and Greece is provided directly by educational institutions, various postgraduate education institutions, education departments, university institutes and regional education centers; among the organizational forms of professional development of scientific and pedagogical workers: propaedeutic, periodic, special advanced training and retraining. In Canada, training of scientific and pedagogical workers is provided by a variety of teacher certification programs; education departments that manage the development of national education policy; regional education centers; unions and private providers of professional development services of scientific and pedagogical workers, whose activities are aimed at organizing training. In China, in-service training takes place in the interaction of in-service training courses, school-based activities and teacher self-education; advanced training is carried out on day, evening, correspondence and distance forms of training and is built taking into account pedagogical experience, level of pedagogical qualification and necessity of methodical improvement.

It was found that in the process of advanced training of scientific and pedagogical workers institutions of higher education institutions of foreign countries special attention is paid to the possibility of permanent access of scientific and pedagogical workers to a new current background on the latest developments, distance learning courses, designing an individual educational route, meeting the educational needs of scientific and pedagogical workers.

Keywords: international experience, advanced training, scientific and pedagogical workers, world educational space, forms and methods of professional development of scientific and pedagogical workers.

Постановка проблеми. В умовах сьогодення відбувається входження України до європейського та світового освітніх просторів, реформування національної системи вищої та післядипломної освіти на принципах гнучкості і варіативності, полікультурності, толерантності, спрямованої на забезпечення мобільності, працевлаштування та конкурентоспроможності фахівців із вищою освітою, підвищення ефективності науково-педагогічної, навчально-методичної та науково-дослідної роботи в закладах вищої освіти. Не менш важливого значення в суспільно-політичному житті та модернізації суспільства XXI століття надається науково-педагогічним працівникам, їх професіоналізму та відповідно системі підвищення кваліфікації.

Неперервна освіта науково-педагогічних працівників у сучасних умовах розуміється як системне поєднання формальної, неформальної та інформальної освіти, що супроводжує професійну сферу. Проблеми якісної підготовки, перепідготовки та підвищення їхньої кваліфікації є актуальною як для України, так і для зарубіжних країн, тому що педагогічна освіта постійно актуалізується у зв'язку з розвитком тенденцій у суспільстві. Їх модернізація й удосконалення 
вимагають вивчення досвіду інших країн, впровадження позитивних надбань у практику професійної підготовки та підвищення кваліфікації науковопедагогічних працівників у нашій країні. Таким чином, для вдосконалення системи підвищення кваліфікації науково-педагогічних працівників України важливо враховувати накопичений міжнародний досвід.

Аналіз останніх досліджень і публікацій. Вагомий внесок у дослідження проблем підвищення рівня професійної компетентності науково-педагогічних працівників шляхом підвищення їхньої кваліфікації зробили такі вчені як: Л. Безтелесна, М. Орлів, А. Печенюк, С. Чернишова, А. Чміль та ін. Питання розвитку системи післядипломної педагогічної освіти розглядали Г. Дегтярьова, I. Зязюн, С. Крисюк, А. Кузьмінський, Н. Ничкало, О. Пєхота, Н. Протасова, В. Соколинський, Т. Сорочан, С. Толочко, М. Ярмаченко та ін. Теоретичні положення щодо підвищення науково-педагогічних і педагогічних працівників у системі післядипломної освіти висвітлені в працях українських (С. Антощук, О. Бабакіна, В. Бондарь, О. Ворожейкіна, А. Зубко, І. Регайло, О. Самойленко, О. Старостіна, Н. Чепурна та ін.) та зарубіжних (Д. Бауме (D. Вaume), Р. Блеквелл (R. Blackwell), П. Блекмор (P. Blackmore), К. Борчард (K. Borchard), М. Брунер (M. Bruner), M. Вальтер (M. Walter), Г. Вебб (G. Webb), В. Веблер (W. Webler), Л. Вільсон (L. Wilson), С. Дані (S. Dany), Л. Елтон (L. Elton), П. Кан (P. Кahn), Х. Леман (H. Lehmann), Е. Майєр (Е. Mayer), Г. Ніколлс (G. Nicholls), Р. Нойман (R. Neumann), M. Ноулз (M. Knowles), С. Роджерс (C. Rogers), К. Сіммондс (K. Simmonds), Л. Сiмop (L. Simor), Дж. Тейлор (J. Taylor), К. Штаркман (K. Shtarkman) учених.

Однак, існує необхідність вдосконалення системи підвищення кваліфікаціі науково-педагогічних працівників у контексті євроінтеграції, шляхом вивчення та узагальнення досвіду інших країн, впровадження позитивних надбань у практику СПК НПП ЗВО України.

Мета статті - проаналізувати міжнародний досвід розвитку системи підвищення кваліфікації науково-педагогічних працівників закладів вищої освіти.

Виклад основного матеріалу. В країнах Свропейського Союзу (СС) велике значення надається професійній підготовці та перепідготовці науковопедагогічних працівників.

Проаналізуємо міжнародний досвід розвитку системи підвищення кваліфікації (СПК) науково-педагогічних працівників (НПП) закладів вищої освіти (ЗВО) на прикладі провідних країн світу.

У сучасних умовах необхідна диференціація й індивідуалізація науковометодичного супроводу в процесі підвищення кваліфікації НПП ЗВО. Із цією метою на прикладі Німеччини, Великобританії, Фінляндії та США в структурних підрозділах 3ВО, відповідальних за підвищення кваліфікації НПП, повинні бути консультанти (або експерти), які розробляли б спільно з НПП його «індивідуальний маршрут» професійного розвитку, що буде сприяти формуванню у кожного НПП позитивне ставлення до безперервного підвищення кваліфікації та самоосвіти. 
Однією 3 можливостей використання позитивного досвіду підвищення кваліфікації НПП Великобританії та США в сучасних умовах вітчизняної педагогічної практики є створення мережі центрів ПК НПП ЗВО, наприклад, філій із координуючим центром в одному 3 провідних закладів вищої освіти України. Такі підрозділі можуть бути, з одного боку, універсальними, і, з іншого боку, спеціалізованими, наприклад, тільки для науково-педагогічних працівників закладів вищої освіти педагогічного або економічного профілю.

У Великобританіі функціонує професійна асоціація співпрацівників і розробників освітніх програм, що просуває інновації й передовий досвід у сфері вищої освіти, «SEDA», до завдань якої віднесено й підвищення професійного та освітнього розвитку кваліфікацій досвідчених і молодих НПП.

Важливо зазначити, що процес підвищення кваліфікації науковопедагогічних працівників закладів вищої освіти в Україні, як і у Великобританії та США, доцільно вибудувати в систему, починаючи від підвищення кваліфікації викладачів-початківців і закінчуючи більш досвідченими науково-педагогічними працівниками закладів вищої освіти, так як деякі форми і методи підвищення кваліфікації різних категорій НПП ЗВО помітно різняться у зв’язку 3 різноплановістю їх підготовки, досвіду та спеціалізації.

У Фінляндії підвищення кваліфікації НПП організовується безпосередньо навчальними закладами, Національною радою з питань освіти (The National Board of Education), Національним центром професійного розвитку в галузі освіти (Тhe National Centre for Professional Development in Education), відділами освіти НПП та іншими факультетами закладів вищої освіти за кредитною системою навчання. Підвищення кваліфікації відбувається в різних формах, зокрема використовують адресне, каскадне, спільне (кооперативне) навчання та навчання на власних прикладах [4].

В країні також впроваджується модель професійного розвитку педагогічних працівників, яка передбачає тісний взаємозв'язок між закладами вищої освіти та закладами загальної середньої освіти. Основна концепція даної моделі полягає в тому, що шкільні вчителі на основі власного щоденного професійного досвіду «тренують» НПП ЗВО. У свою чергу викладачі ЗВО розповідають вчителям про останні дослідження у напрямі різноманітних аспектів вивчення та методології освіти на основі власного досвіду. Крім цього, передбачаються спільні щорічні семінари та педагогічні дні [12].

У Німеччині ПК НПП також відбувається в академіях та інститутах підвищення кваліфікації, професійних спілках, асоціацій (можуть бути і церкви, банки, видавництва тощо). У зв’язку з цим ПК НПП кадрів носить державногромадський характер.

Сучасна післядипломна педагогічна освіта Греції спрямована на реалізацію концепції неперервної освіти, проєктування єдиної системи накопичення навчальних одиниць під час післядипломної підготовки, удосконалення знань та вмінь без відриву від роботи, адаптацію та підтримку молодих учителів. Серед організаційних форм професійного розвитку НПП: пропедевтичне, періодичне, 
спеціальне підвищення кваліфікації та перепідготовка [10].

Підвищення кваліфікації НПП та педагогічних працівників у Франції забезпечується різноманітними установами післядипломної освіти, університетськими інститутами та регіональними центрами освіти. Вона покликана допомогти педагогам відновити їх професійні знання і в той же час переорієнтувати їх відповідно до реальних проблем закладів вищої та загальної середньої освіти, відповідно до потреб суспільства. У СПК НПП ЗВО Франції використовують методи демонстрації педагогічних відеофільмів, моделювання, мікро-викладання, «міні-курси», рольові ігри, презентації проєктів, телекомунікаційні та інформаційні технології тощо [5].

У Канаді підвищення кваліфікації НПП забезпечується різноманітними програмами сертифікації педагогів; департаментами освіти, які управляють розвитком національної політики в галузі освіти; регіональними центрами освіти, що аналізують сучасний стан педагогічної професії, визначають іiі переваги та недоліки; волонтерськими предметними асоціаціями НПП; спілками НПП та приватними постачальниками послуг професійного розвитку, діяльність яких спрямована на організацію підвищення кваліфікації. Фінансування професійного розвитку НПП забезпечують Департаменти/Міністерства освіти провінцій Канади [7].

У Китайській народній республіці (КНР) підвищення кваліфікації НПП відбувається у взаємодії курсів підвищення кваліфікації, заходів на базі навчального закладу та самоосвіти педагога. Для цього використовується кредитно-накопичувальна система, яка забезпечує можливість врахування досягнень педагогів не тільки під час навчання на курсах підвищення кваліфікації, а й у міжкурсовий період на рівні навчального закладу. Підвищення кваліфікації здійснюється за денною, вечірньою, заочною та дистанційною формами навчання й будується 3 урахуванням педагогічного стажу, рівня педагогічної кваліфікації й необхідності методичного удосконалення [6].

Відповідно до програми розвитку інформаційного суспільства у КНР функціонує Національний Інтернет-альянс педагогічної освіти - координаційний орган навчання НПП, що забезпечує синтез дистанційного, очного навчання i самоосвіти, та об'єднує в собі кращі освітні ресурси. Мета створення Інтернетальянсу у КНР полягає у реалізації великомасштабного, високоякісного, економічно вигідного проєкту ефективної післядипломної педагогічної освіти 3 використанням сучасних технологій та різних програм навчання [11].

Таким чином, з'ясовано, що підвищення кваліфікації у вищезазначених країнах має забезпечувати особистісні потреби НПП у професійному розвитку.

На сьогодні у зарубіжних країнах склалося науково-технічне партнерство держави, університетів та бізнесу, що дає можливість об'єднати ресурси для ПК НПП ЗВО шляхом надання грантів. Так, у Великобританії існують такі грантові фонди: «Лондонське королівське товариство» («The Royal Society»), «Благодійний фонд Джеймса Дайсона» («The James Dyson Foundation»), «The Wellcome Trust» (фінансує дослідження у галузі медицини) тощо. 
У Німеччині: «Фонд Готліба Даймлера та Карла Бенца» («Daimler und Benz Stiftung») (надає гранти аспірантам у проведенні досліджень у німецьких 3 ВО 3 метою написання дисертації; щороку присуджує «Премію Берти Бенц» - молодій ученій-інженеру, яка представила видатну докторську дисертацію), «Об'єднання імені Гельмгольца» («Helmholtz-Gemeinschaft Deutscher Forschungszentren») (фінансує дослідження за шістьма напрямами: енергія; земля і екологія; охорона здоров'я; інноваційні технології; структура матерії; авіація, космос і транспорт), «Фонд Фріца Тіссена» («Fritz Thyssen Stiftung»), «DAAD» («Deutscher Akademischer Austauschdienst» - німецька служба академічних обмінів, яка об’єднує всі німецькі ЗВО та сприяє розвитку академічних відносин за кордоном, перш за все за допомогою обміну здобувачів вищої освіти та НПП), «Deutsche Forschungsgemeinschaft» (найбільше німецьке науково-дослідне товариство Німеччини, що підтримує проєкти, які реалізуються у ЗВО Німеччині), «Фонд Фрідріха Еберта» («Friedrich-Ebert-Stiftung»), «Фонд Герди Хенкель» («The Gerda Henkel Foundation») (фінансує дослідження у галузі історичних і гуманітарних наук), «Фонд Фольксваген» («Volkswagen Stiftung») (фінансує дослідження у галузі гуманітарних і соціальних наук, академічні освітні проєкти, переклади науково-методичної літератури, спеціальні програми ПК молодих НПП, літні школи та літні курси (максимальна кількість учасників - 60) та симпозіуми (не більше 30 учасників), «Фонд Александера фон Гумбольдта» («Alexander von Humboldt-Stiftung») (підтримує наукове співробітництво між видатними зарубіжними та німецькими НПП) тощо.

У США існує «Національний науковий фонд» («National Science Foundation»), який $є$ джерелом фінансування приблизно 24 \% усіх підтримуваних на федеральному рівні фундаментальних досліджень, у багатьох галузях (математика, інформатика, соціальні науки тощо). «Національний інститут здоров'я» («National Institutes of Health») фінансує дослідження в біології i медицині. «Фонд цивільних досліджень і розвитку» («CRDF Global») надає гранти та технічні ресурси НПП для проведення досліджень у галузі прикладних і фундаментальних наук тощо [1, С. 343-345].

Аналогічна тенденція починає активно впроваджуватися й в Україні. Так, у 2018 році відповідно до Закону України «Про наукову і науково-технічну діяльність», було створено державну бюджетну установу - Національний фонд досліджень України (НФДУ) - для підтримки та фінансування фундаментальних та прикладних досліджень, що проводяться НПП ЗВО або наукових установ. Згідно із законодавством НФДУ є спеціальним інструментом реалізації державної політики, за допомогою якого здійснюється фінансування заходів, спрямованих на всебічний розвиток української науки як основного чинника економічного зростання держави. Діяльність Фонду спрямована на створення сприятливих умов для максимальної реалізації інтелектуального потенціалу громадян у сфері наукової і науково-технічної діяльності на принципах змагальності та наукового лідерства [8].

Основними принципами, якими керується НФДУ у своїй діяльності 
є: максимальна відкритість та прозорість; незалежність та об'єктивність наукової i науково-технічної експертизи проєктів 3 виконання наукових досліджень i розробок; повага і дотримання авторських та суміжних прав, а також принципів наукової етики; дотримання засад доброчесної конкуренції; запобігання конфлікту інтересів під час вибору членів органів управління Фонду та під час організації конкурсного відбору і фінансування проєктів з виконання наукових досліджень і розробок [8].

Щороку присуджуються премії Президента України за видатні досягнення у сфері природничих, технічних та гуманітарних наук, які сприяють подальшому розвитку науки, суспільному прогресу i утверджують високий авторитет вітчизняної науки у світі. Надаються гранти Президента України для підтримки наукових досліджень молодих учених, премії Кабінету Міністрів України за особливі досягнення молоді у розбудові України, Стипендії Кабінету Міністрів України для молодих учених, гранти Президента України для обдарованої молоді [2].

Однак, більшість вітчизняних ЗВО беруть участь у конкурсі на отримання гранту в міжнародних фондах i програмах обміну: «Фонд імені Конрада Аденауера» (Німеччина), «Фонд навчання Палати депутатів Берліна», «Фонд Александера фон Гумбольдта», «Програма академічних обмінів імені Фулбрайта» (США), «Програма підтримки адміністрування університетів» (США), «Стипендіальна програма імені Вейденфельда» (Великобританія), «DAAD» (Німеччина), «Еразмус +» тощо.

Позитивний є досвід британської системи підвищення кваліфікації НПП ЗВО Великобританії, в основі якого лежать ідеї корпоративного освіти та мережевого підходу.

Використання ідей корпоративної освіти в практиці підвищення кваліфікації науково-педагогічних працівників України дозволить планувати освітню політику з розвитку професіоналізму НПП ЗВО, їх корпоративних цінностей $\mathrm{i}$ культури, здатних швидко та гнучко реагувати на внутрішні і зовнішні зміни в соціально-економічному середовищі на короткостроковий і довгостроковий періоди.

Поряд із ідеями корпоративної освіти особливий інтерес представляють ідеї мережевого підходу, які успішно використовується в умовах ПК НПП ЗВО Великобританії. В основі мережевого підходу запозичено ідею мережевої взаємодії, під якою розуміється узгодження дій суб'єктів мережі для досягнення загальних цілей інноваційного розвитку, що виникає за умови спільної колективної розподіленої діяльності, яка включає сукупність відносин між усіма суб'єктами інноваційного розвитку ЗВО. Мережева взаємодія НПП ЗВО Великобританії простежується в системі «наука - освіта - бізнес» [1, с. 346].

Використання практики встановлення взаємодії НПП ЗВО України, перш за все, усередині самого ЗВО, потім із ЗВО-партнерами, а також зі стейкхолдерами, представниками промисловості, бізнесу та науки у вітчизняній СПК НПП ЗВО, посилить і примножить іiі інноваційну складову. Тільки об’єднаними зусиллями 
можливо досягти бажаного ефекту щодо вдосконалення якості науковопедагогічного потенціалу ЗВО.

Важливим i корисним $\epsilon$ міжнародний досвід щодо організації аспірантури/докторантури.

Особливістю системи підготовки НПП США є створення ради 3 П’яти членів для кожного захисту дисертації, як правило, із НПП даного університету. В основі діяльності американських 3ВО лежить принцип академічної свободи, заснований на переконаності, що НПП чесний у своєму науковому пошуку і має достатньо знань для того, щоб оцінити результати праці інших НПП. Тому, в американській системі захисту не прийняті такі форми формальної експертизи, як письмові відгуки на дисертацію. Роль членів комісії у процесі захисту зводиться до постановки питань і до оцінки якості проведеної роботи. Уважаємо, що цей позитивний приклад дозволяє збагатити дисертаційну роботу і науку в цілому, так як у підсумковому варіанті дослідження в певній мірі буде відображена робота спеціалізованої вченої ради ЗВО.

У системах підготовки НПП Німеччини, Великобританії та США процес захисту дисертації має публічний характер. Відповідальність за якість і терміни навчання в аспірантурі/докторантурі покладається на ЗВО (факультет, кафедру) [1, с. 347].

Аналогічна тенденція починає активно впроваджуватися й в Україні. Так, 6 березня 2019 року КМУ затверджено Постанову «Про проведення експерименту 3 присудження ступеня доктора філософії», в межах якого висвітлені «питання проведення експерименту 3 присудження ступеня доктора філософії спеціалізованими вченими радами закладів вищої освіти (наукових установ), встановлення вимог до рівня наукової кваліфікації осіб, які здобувають ступінь доктора філософії, утворення спеціалізованих вчених рад закладів вищої освіти (наукових установ) та скасування їх рішень» [9]. Відповідно до нього опонентами можуть бути іноземні вчені 3 наукового напряму, за яким підготовлено дисертацію здобувача вищої освіти.

Конструктивним є досвід співпраці центрів ПК НПП ЗВО Німеччини, Великобританіі та США 3 провідними спеціалізованими підрозділами як всередині своєї країни, так і за кордоном (Італія, Франція, Чехія, Канада, Африка, Австралія тощо). Підтвердженням цього $є$ проведення постійних міжнародних симпозіумів i конгресів із питань організації ПК НПП ЗВО, спільних майстер-класів, укладання договорів про участь НПП, здобувачів вищої освіти за програмою академічної мобільності. Однією з умов міжнародного співробітництва $є$ вивчення та знання іноземних мов. Це дає можливість проходити стажування за кордоном, брати участь у міжнародних науковопрактичних конференціях, семінарах, круглих столах, вивчати зарубіжну науково-педагогічну та спеціальну літературу, ознайомитися із сучасними технологіями та досягненнями у сфері науки.

Досвід формування змішаних навчальних груп (фокус-груп, дослідницьких груп, дискусійних груп тощо) на курсах ПК НПП ЗВО США становить особливий 
інтерес для української СПК. Створення змішаних навчальних груп, до яких входять НПП різного профілю, сприяють ефективному засвоєнню навчального матеріалу та розвитку у них креативності. У зв'язку з цим працівники центрів ПК НПП ЗВО створюють сприятливі умови, що стимулюють розвиток творчого мислення у слухачів: організація розминок; дозвіл і заохочення безлічі питань; акцент на активності і самостійності; відсутність різкої критики; зосередження уваги до інтересів і потреб НПП. Так, наприклад, на заняттях у змішаних групах мимоволі демонструється ступінь вміння креативно й оперативно вирішувати завдання, орієнтуватися в стандартних i нестандартних умовах. Отже, створюються в цілому більш сприятливі передумови для успішного професійного й особистісного розвитку, саморозвитку i самореалізації НПП у процесі їх підвищення кваліфікації.

Використання різноманітних форм, методів і засобів навчання на курсах ПК НПП 3ВО Німеччини, Великобританії та США є також позитивним.

У Німеччині активно розвивається онлайн ПК НПП. Серед інноваційних форм ПК виокремлюють модераторство, педагогічне проєктування, блочномодульне навчання із застосуванням ігрових технологій навчання тощо.

У Великобританії провідними формами ПК НПП є: каскадна форма навчання; форми професійного росту, пов'язані з певним етапом кар'єрного зростання НПП; індивідуальне підвищення кваліфікації, що відповідає особистим інтересам та професійним потребам конкретного НПП. Особливу увагу привертають такі форми як: стипендії для вивчення кращого педагогічного досвіду, програми вивчення міжнародного досвіду, програми творчих відпусток тощо.

У США із усього різноманіття використовуваних форм ПК (відкрите заняття, лекція, семінар, індивідуальна консультація, спільноти НПП, аудиторні спостереження тощо) найбільш широке поширення набули майстерні. Вони дозволяють ефективно реалізовувати зміст програм ПК НПП ЗВО на основі принципів особистісного i творчого розвитку, активної взаємодії слухачів і практичної спрямованості їх діяльності.

Використання широкого спектра методів у СПК НПП ЗВО Німеччини, Великобританії та США також може сприяти ефективному ПК НПП ЗВО України. Для СПК НПП ЗВО України інтерес викликають проблемні методи («Навчання дією», «Спостереження за роботою колег», «Снігова куля», «Шість капелюхів мислення» тощо), методи латерального мислення («Альтернативи», «Віяло концепцій», «Фокусування», «Виклик», «Випадковий стимул», «Провокація і рух», «Збір ідей», «Обробка ідей»), «DATT», статистичні методи TSED i TSEIC тощо. Застосування цих методів сприятимуть підвищенню мотивації й активізації професійної діяльності вітчизняних НПП, а також дозволять їм встановити баланс між різними сферами життя та уникнути критичних ситуацій. Загалом ці методи спрямовані на розвиток у слухачів комунікативної компетенції, тобто здатності НПП до активного спілкування, вмінню слухати, грамотно та коректно ставити питання й чітко формулювати 
відповіді на них, уважно слухати і активно обговорювати розглянуті проблеми, коментувати висловлювання співрозмовників і давати їм, у разі необхідності, конструктивну пораду, аргументувати свою думку в групі [1, с. 351].

Для адаптації НПП-початківців до умов їх майбутньої роботи адміністрацією ЗВО Великобританії надається низка можливостей для ознайомлення 3 особливостями організації та освітньої політики ЗВО. Уважаємо, що «менторинг» або «наставництво» $є$ позитивним методом «уведення в професію» такого НПП на його робочому місці, для досвідчених НПП варто пропонувати варіативні курси ПК, які вони можуть відвідувати в зручний час або дистанційно.

Різноманітність сучасних засобів, які використовуються в процесі ПК НПП ЗВО Німеччини, Великобританії, Фінляндії, Греції, Канади та США, безсумнівно, гарантує його високу ефективність. Цьому сприяють сучасні інтерактивні засоби навчання. Використання їх у процесі ПК НПП дозволяє значно підвищити рівень взаємодії між наставником i НПП та успішно і ефективно розвивати комунікативні та цифрову компетенції у НПП. Комплекс апаратних засобів, в основному, складається з комп'ютера, інтерактивної дошки, мультимедійного проектора та пристроїв зв'язку (web-камера, система передачі даних, адаптер тощо) [3].

Однак, потрібно враховувати, що зарубіжний досвід у використанні інтерактивних засобів в освітньому процесі не унікальний. Українські ЗВО здебільшого вже оснащені таким обладнанням.

Висновки. У процесі ПК НПП ЗВО зарубіжних країн особлива увага приділяється можливості постійного доступу НПП до нового актуального бекграунду щодо новітніх розробок, дистанційних курсів ПК тощо. У зв'язку з цим у СПК НПП ЗВО міжнародних країн створюють власні цифрові освітні простори, що забезпечують нові можливості для: переходу від навчання в аудиторії до віртуального навчання в різних місцях і в різний час, тим самим розвиваючи цифрову компетентність НПП за рахунок впровадження цифрових технологій; проєктування індивідуального освітнього маршруту, задоволення освітніх потреб особистості НПП.

\section{Лimepamypa:}

1. Бабакіна О.О. Розвиток системи підвищення кваліфікації науково-педагогічних працівників закладів вищої освіти України останньої чверті XX - початку XXI століття : дис. ... докт. пед. наук : 13.00.01, 13.00.06. Старобільськ, 2021. 715 с.

2. Довідник. Вітчизняні та іноземні гранти, стипендії, конкурси для молодих науковців і студентів України. URL : https:/science.udau.edu.ua/assets/files/rmu/grantiprezedenta.pdf (дата звернення : 09.09.2021).

3. Інтерактивні засоби навчання. URL : https://sites.google.com/site/internetunavcanni/ interaktivni-zasobi-navcanna (дата звернення : 25.08.2021).

4. Ковальчук В. Професійний розвиток учителів: зарубіжний досвід. URL http://education-ua.org/ua/porivnyalna-pedagogika/485-profesijnij-rozvitok-uchiteliv-zarubizhnijdosvid (дата звернення : 13.08.2021).

5. Корсак К. В., Гранюк Л. О. Франція: післядипломна освіта та пї досягнення. Післядипломна освіта в Україні : зб. наук. пр. Київ, 2001. №1. С. 28-31. 
6. Котельнікова Н. М. Система післядипломної освіти вчителів у Китаї : дис. ... канд. пед. наук : 13.00.01. Луганськ, 2012. 274 с.

7. Мукан Н. Система неперервної професійної освіти педагогів Канади: інституції та їхня діяльність. Вісник Львівського університету : зб. наук. пр. Серія: Педагогічна. 2007. Вип. 22. C. 227-231.

8. Національний фонд досліджень України. URL : https://nrfu.org.ua/about-us/the-missionand-purpose-of-the-foundation/ (дата звернення : 18.09.2021).

9. Про присудження ступеня доктора філософії : Постанова Кабінету Міністрів України від 6 березня 2019 р. № 167. URL : https://zakon.rada.gov.ua/laws/show/167-2019-\%D0\%BF\#Text (дата звернення : 30.09.2021).

10. Проценко О. Б. Система післядипломної педагогічної освіти в Греції : автореф. дис. ... канд. пед. наук : 13.00.04. К., 2009. 21 с.

11. Шацька О. П. Розвиток вищої педагогічної освіти в Китаї (70-ті pp. XX - початок XXI століття) : дис. ... канд. пед. наук : 13.00.01. Луганськ, 2012. 250 с.

12. Asunta T. Developments in Teacher Education in Finland. In-service Education and Training. Seminar on Modernization of Study Programmes in Teachers' Education in an International Context. Ljubljana, 2006, P. 142-143.

\section{References:}

1. Babakina, O.O. (2021). Rozvytok systemy pidvyshchennia kvalifikatsii naukovopedahohichnykh pratsivnykiv zakladiv vyshchoi osvity Ukrainy ostannoi chverti XX - pochatku XXI stolittia [Advancing the system of academic staff professional development in Ukraine from the mid 1970s to the beginning of the 21st century]. Doctor's thesis. Starobilsk [in Ukrainian].

2. Dovidnyk. Vitchyzniani ta inozemni hranty, stypendii, konkursy dlia molodykh naukovtsiv i studentiv Ukrainy [Directory. Domestic and foreign grants, scholarships, competitions for young scientists and students of Ukraine]. science.udau.edu.ua. Retrieved from https://science.udau.edu.ua/assets/ files/rmu/grantiprezedenta.pdf [in Ukrainian].

3. Interaktyvni zasoby navchannia [Interactive learning tools]. sites.google.com. Retrieved from https://sites.google.com/site/internetunavcanni/interaktivni-zasobi-navcanna [in Ukrainian].

4. Kovalchuk, V. Profesiinyi rozvytok uchyteliv: zarubizhnyi dosvid [Professional development of teachers: foreign experience]. education-ua.org. Retrieved from http://education-ua.org/ua/porivnyalnapedagogika/485-profesijnij-rozvitok-uchiteliv-zarubizhnij-dosvid [in Ukrainian].

5. Korsak, K.V., Hraniuk, L.O. (2001). Frantsiia: pisliadyplomna osvita ta yii dosiahnennia [France: postgraduate education and its achievements]. Pisliadyplomna osvita v Ukraini - Postgraduate education in Ukraine, 1, 28-31 [in Ukrainian].

6. Kotelnikova, N.M. (2012). Systema pisliadyplomnoi osvity vchyteliv u Kytai [Postgraduate teacher education system in China]. Candidate's thesis. Luhansk [in Ukrainian].

7. Mukan, N. (2007). Systema neperervnoi profesiinoi osvity pedahohiv Kanady: instytutsii ta yikhnia diialnist [The system of continuing professional education of Canadian teachers: institutions and their activities]. Visnyk Lvivskoho universytetu - Bulletin of Lviv University, 22, 227-231 [in Ukrainian].

8. Natsionalnyi fond doslidzhen Ukrainy [National Research Fund of Ukraine]. nrfu.org.ua. Retrieved from https://nrfu.org.ua/about-us/the-mission-and-purpose-of-the-foundation/ [in Ukrainian].

9. Pro prysudzhennia stupenia doktora filosofii [On awarding the degree of Doctor of Philosophy] (2019, March 6). Postanova Kabinetu Ministriv Ukrainy vid 6 bereznia 2019 r. № 167 - Resolution of the Cabinet of Ministers of Ukraine of March 6, 2019 № 167. zakon.rada.gov.ua. Retrieved from https://zakon.rada.gov.ua/laws/show/167-2019-\%D0\%BF\#Text [in Ukrainian].

10. Protsenko, O.B. (2009). Systema pisliadyplomnoi pedahohichnoi osvity v Hretsii [The system of postgraduate pedagogical education in Greece]. Extended abstract of candidate's thesis [in Ukrainian]. 
11. Shatska, O.P. (2012). Rozvytok vyshchoi pedahohichnoi osvity v Kytai (70-ti rr. XX pochatok XXI stolittia) [Development of higher pedagogical education in China (70s of the XX beginning of the XXI century)]. Candidate's thesis. Luhansk [in Ukrainian].

12. Asunta, T. (2006). Developments in Teacher Education in Finland. In-service Education and Training. Seminar on Modernization of Study Programmes in Teachers' Education in an International Context, 142-143 [in English]. 